\title{
The Role of Professional Labor Migration in Developing an Effective Knowledge Management System in High-Technological Organization
}

\author{
Karina V. Sayapina \\ Department of Management \\ Financial University under the Government of the Russian Federation \\ Moscow, Russia \\ k.v.sayapina@gmail.com
}

\begin{abstract}
The paper is devoted to search of instrument, based on labor migration aspect and consequent cross-cultural peculiarities, for building an effective knowledge management system in high-tech company. The instrument is approved by case study method in large international high-tech corporations.
\end{abstract}

Key words: knowledge management; cross-cultural factors, high-tech organization; labor migration .

\section{INTRODUCTION}

Modern problems and tendencies in labor migration are the object of important large-scale research during recent years. Studies in labor migration sphere are especially actual in European continent. It is because of multinational economic area of the "Big Europe", including Russia, outside of the EU, and of intensifying labor migration processes in conditions of developing economic, social and cultural contacts in a global world. Research of labor migration processes from the CIS countries are also of great meaning, so far as with education and general liberalization in sphere of labor migration there, this aspect nowadays is of mass proportions with serious social, economic and political consequences.

Nowadays society goes through active process of globalization: there is constant exchange of information, technologies and other resources, including human ones, in different organizations' activity. Development and acceleration of such exchange are realized so fast, that a company being without international status, however, could consist of representatives from different nations and cultures all over the world. On the other part, in high-technological companies management aims to create multinational multicultural teams in order to form special unique atmosphere for interaction of different ideas and scientific schools to increase effectiveness in elaborating new strategy course, and thus to have a resultant knowledge management system. That is why for managers, responsible for decision-making process, significance of taking into account cross-cultural peculiarities in organizational strategy is risen. This is also of significant importance, because for number of actively developing "knowledge economy" sectors forming, necessary team of specialists is realized by mean of labor migration, i.e.attraction of high-qualified personnel from different states all over the world.

\section{LITERATURE REVIEW}

In evolutionary development of strategic management theories, increasing role of accounting cross-cultural aspect in forming knowledge management system has already been traced by the end of XX century [6].

First works in sphere of strategic management appeared in 60 -s of XX century. Here, the main accent was absolutely in industrial and financial aspects. One of the main founders of this course is I. Ansoff (martix "product-market", "Scheme of strategic planning", hierarchy of aims and strategies of organization) [1]. In 70-s of XX century results of his work were continued in further development by Harvard Business School: SWOT-analysis was elaborated (which is strengths, weaknesses, opportunities and threats) in frames of accounting internal and external factors of organization's activity [4]. In the same period, R. Normann designed a concept of building strategy on basis of business-idea (target segment identification, product formation under needs in this segment, creation of internal organization due to its actives, structure and management procedures) [13]. This concept was improved in the end of 70-s by $\mathrm{Ch}$. Hofer and D. Schendel: knowledge effectiveness strategy formation is realized in terms of special algorithm: market identification and searching company's main competences, forming competitive advantage, search of synergy inside the company [9]. In 80-s M. Porter, taking into account sharpened competition, developed a concept of industry's competitive analysis, competitive advantage (with formation of further appropriate strategy) and value chain [14]. In 90-s, in conditions of business environment changes, theories of knowledge management were elaborated on basis of internal and external organizational environment (which is necessity to react on these changes and search for new decisions in context of macroeconomic factors) [12]. However, these factors also had rationally technical character, and problems of cross-cultural aspect hasn't still been taken into account. It was H. Minzberg theory about forming knowledge management system in terms of organization's internal resources development, where for the first time cross-cultural aspect has been reminded; it is realized through special personnel 'school of training' improving its professional skills and methods of mutual interaction. The main task of interaction control was to solve potential cross-cultural problems in organization [11]. 
In Russian exploratory society, publications of $\mathrm{S}$. Ryazantsev play significant role, where impact of labor migration in knowledge management system are estimated, mainly in the Commonwealth of Independent States (CIS) and Baltic countries, and in the European Union (EU), in the USA, in the BRIC countries (Brazil, Russia, India and China) [15].

Specified review of existing theoretical works towards building an effective knowledge management system shows frames and limitations in existed approaches to investigation of this problem, because cross-cultural difficulties as a natural consequence of global labor migration are insufficiently considered in these approaches.

\section{THEORETICAL GROUNDING \& METHODOLOGY}

The research of influencing professional labor migration aspect and appropriate cross-cultural factors in building knowledge management system is held in two stages. On the first stage analysis of common knowledge management system, used mainly in high-technological organizations where culture is considered as one of its resources, is held (Fig. 1).

According to the model, solving of definite tasks is realized by cultural factors, which work as internal stimuli influenced on knowledge management system of a company. Unique knowledge, created on basis of different types of resources, and common knowledge, cultural knowledge and cross-cultural technologies, is a competitive advantage of a company. Due to analysis of market reaction towards this competitive advantage, necessary improvements and changes in its internal structure are realized, and these changes are faster and more qualitative respond to market needs of definite region. That's why a company could be equal here to "portfolio of abilities, not types of business" [8, p. 29].

It is necessary to underline that simple recruitment process on international level is not so effective in context of potential cross-cultural problems. Thus, in frames of preventing possible negative consequences in this process, and due to importance of cross-cultural technologies aspect, the author suggests algorithm of attracting foreign specialists, and immediate solution of crosscultural problems (Fig. 2).

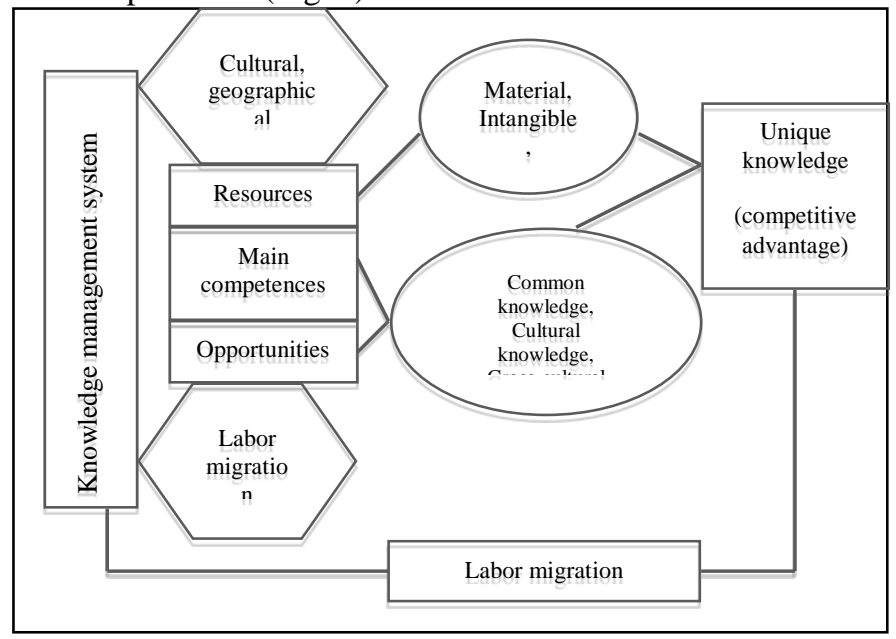

Fig. 1. Model of organizational functioning in frames of culture factor (made by the author on basis of $[5 ; 7 ; 8 ; 10]$ )

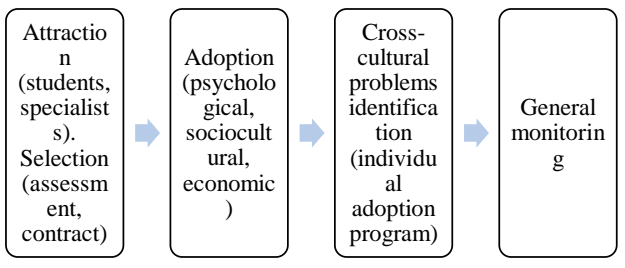

Fig. 2. Algorithm of acctracting foreign specialists in organization

Attraction stage assumes involvement of the most talented, successful and smart students from leading higher educational institutions all over the world in appropriate high-tech industry, and similar specialists in country of origin and abroad. It can be realized by competitive intelligence method, active cooperation with international organizations in appropriate sphere, and through participation in international conferences, seminars and forums. Selection consists of assessment process of specialists attracted (interviewing, identifying professional and communicational skills), and signing contract with selected foreign specialist under mutual agreement.

Adoption stage is really important and supposes psychological adoption (achievement of psychological satisfaction inside new environment depending on personal abilities of foreign specialist and his expectations towards new place of life and work, his internal family atmosphere), sociocultural adoption in country of origin (on basis of acquiring social skills, solving socio-cultural problems in everyday life, and active involvement of foreign specialist in cultural life of the country), and economic adoption through special educational programs, studying on working place, trainings and motivation program for personnel.

Cross-cultural problems identification stage is built on principals of assigning definite code of rules to simplify communication and overcome interactional barriers inside personnel, analysis of specialist's communication among staff, and concrete difficulties, appearing in this process; analysis of cultural similarities and differences, leading to misunderstanding among staff; and analysis of appearing conflict situations inside organization. Then special individual adoption program is elaborated, which main goal is to hold the fastest and painless homogeneous adoption of foreign specialist on basis of the following factors:

- cultural differences of foreign specialist in comparison with culture of the country of origin;

- spectrum of duties for specialist in context of his level of professional language, which is official working language in an organization;

- expectations of foreign specialist towards new work; 
- life perception by foreign specialist: personal perception of cultural environment in the country of origin, perception of business atmosphere inside organization;

- personal attitude of foreign specialist to moral norms and traditions of the country of origin;

TABLE I. CROSS-CULTURAL PARAMETERS SYSTEM

\begin{tabular}{|c|c|c|}
\hline Factors & Parameter & Meaning \\
\hline \multirow{3}{*}{ Cultural } & Foreign specialists, $\%$ & 30 \\
\hline & $\begin{array}{l}\text { Specialists with higher education diploma, } \\
\%: \\
\quad \text { total } \\
\text { including foreigners }\end{array}$ & $\begin{array}{l}70 \\
25\end{array}$ \\
\hline & $\begin{array}{l}\text { Specialists with Ph.D. degree, } \%: \\
\text { total } \\
\text { including foreigners }\end{array}$ & $\begin{array}{l}10 \\
50\end{array}$ \\
\hline \multirow{2}{*}{ Branding } & SME grants, $\%$ (in total financing) & 2 \\
\hline & $\begin{array}{l}\text { Membership in international associations, } \\
\text { (minimum level of participation) }\end{array}$ & $3-5$ \\
\hline Economic & $\begin{array}{l}\text { Venture investment projects, \% (in total } \\
\text { financing) }\end{array}$ & 10 \\
\hline \multirow[b]{2}{*}{ Institutional } & $\begin{array}{l}\text { Number of foreign specialists attraction } \\
\text { programs }\end{array}$ & $5-7$ \\
\hline & $\begin{array}{l}\text { Number of exchange education programs } \\
\text { (including qualification and experience } \\
\text { exchange) }\end{array}$ & $3-5$ \\
\hline
\end{tabular}

Finally, general monitoring stage is held by interviewing, questionnaire poll, and planned meetings with HR-manager (or psychologist) with discussion of potential problems during interaction process among staff, in society during free time. It is also important to estimate turnover control, volume of hiring and dismissal, expenditures on personnel by different reasons, and to make plan of estimation for more operative and strategic decisions in terms of human resources management and knowledge management system in organization.

The second stage of the research is devoted to assessment of cross-cultural factors by case-study method for two international high-technological companies ("Arkema" and "BIOCAD") on basis of the specially elaborated cross-cultural parameters system as a result of cross-cultural analysis of main Silicon Valley high-tech companies (Tabl. 1).

After cross-cultural factors assessment elaboration of practical recommendations for using the instrument of attracting high-qualified foreign personnel in high-tech industry is held.

\section{EMPIRICAL ANALYSIS}

Two large high-technological corporations (French organization "Arkema", specialised in industrial and special chemistry, and Russian biopharmaceutical organization "BIOCAD") are good examples of using cross-cultural factors in frames of buidling effective knowledge management system.

In 2017 sales volume in Arkema corporation was 8,3 bln euro (with almost $3 \%$ of which was dedicated to R\&D direction) [2]. In the end of 2017 total number of specialists was 19800 (where $47 \%$ are from France, $13 \%$ - other EU states, $18 \%$ - the USA, $20 \%$ - Asian countries) [2]. In frames of common knowledge management system, maximisation of personnel abilities is achieved through internal experience exchange in the corporation's subsidiaries (France, Belgium, Denmark, Germany, Hungary, Italy, Poland, Spain, Russia, Switzerland, Great Britain, USA, Canada, Australia, Brazil Algeria, UAE, Egypt, Turkey, Japan, China, India, Malaysia, South Korea, Thailand).

TABLE II. CROSS-CULTURAL PARAMETERS SYSTEM: ARKEMA \& BIOCAD

\begin{tabular}{|c|c|c|c|c|}
\hline Factors & Parameter & Meaning & Arkema & BIOCAD \\
\hline \multirow{3}{*}{ Cultural } & $\begin{array}{l}\text { Foreign } \\
\text { specialists, \% }\end{array}$ & 30 & $\begin{array}{c}25 \\
\text { (rank } \\
0,83)\end{array}$ & $\begin{array}{c}12 \\
(\text { rank 0,4) }\end{array}$ \\
\hline & $\begin{array}{l}\text { Specislists with } \\
\text { higher education } \\
\text { diploma, \%: } \\
\text { total } \\
\text { including } \\
\text { foreigners }\end{array}$ & $\begin{array}{l}70 \\
25\end{array}$ & $\begin{array}{l}25 \text { (rank } \\
0,83) \\
40 \quad \text { (rank } \\
1,6)\end{array}$ & $\begin{array}{c}12(\mathrm{rank} \\
0,4) \\
20 \% \text { (rank } \\
0,8) \\
\end{array}$ \\
\hline & $\begin{array}{l}\text { Specialists with } \\
\text { PhD degree, } \%^{\wedge} \\
\text { total } \\
\text { including } \\
\text { foreigners }\end{array}$ & $\begin{array}{r}10 \\
50\end{array}$ & $\begin{array}{l}8 \text { (rank } \\
\quad 0,8) \\
40 \quad(\text { rank } \\
0,8)\end{array}$ & \begin{tabular}{ll}
\multicolumn{2}{c}{6 (rank } \\
\multicolumn{2}{c}{$0,6)$} \\
15 & (rank \\
$0,3)$ &
\end{tabular} \\
\hline \multirow[b]{2}{*}{ Branding } & $\begin{array}{l}\text { SME grants, \% (in } \\
\text { total financing) }\end{array}$ & 2 & $\begin{array}{c}0,5 \text { (rank } \\
0,25)\end{array}$ & $\begin{array}{c}0 \\
\text { (rank 0) }\end{array}$ \\
\hline & $\begin{array}{l}\text { Membership in } \\
\text { international } \\
\text { associations } \\
\text { (minimum level of } \\
\text { participation) }\end{array}$ & $3-5$ & $\begin{array}{c}\text { More } \\
\text { than } 5 \\
(\operatorname{rank} 1)\end{array}$ & $\begin{array}{l}\text { More than } \\
5 \text { (rank 1) }\end{array}$ \\
\hline Economic & $\begin{array}{l}\text { Venture } \\
\text { investment } \\
\text { projects, \% (in } \\
\text { total financing) }\end{array}$ & 10 & $\begin{array}{l}7 \\
(\text { rank 0,7) }\end{array}$ & $\begin{array}{l}5 \\
(\operatorname{rank} 0,5)\end{array}$ \\
\hline \multirow[b]{2}{*}{$\begin{array}{l}\text { Institu- } \\
\text { tional }\end{array}$} & $\begin{array}{l}\text { Number of foreign } \\
\text { specialists } \\
\text { attraction } \\
\text { programs }\end{array}$ & $5-7$ & $\begin{array}{l}2 \quad \text { (rank } \\
0,4)\end{array}$ & $5(\operatorname{rank} 1)$ \\
\hline & $\begin{array}{l}\text { Number of } \\
\text { exchange } \\
\text { education } \\
\text { programs } \\
\text { (including } \\
\text { qualification and } \\
\text { experience } \\
\text { exchange) }\end{array}$ & $3-5$ & $\begin{array}{l}\text { More } \\
\text { than } 5 \\
(\text { rank 1) }\end{array}$ & $\begin{array}{l}\text { More than } \\
5 \text { (rank 1) }\end{array}$ \\
\hline \multicolumn{3}{|c|}{ Sum of ranks } & 8,16 & 5,57 \\
\hline
\end{tabular}

Unique knowledge of "Arkema" corporation is created through the following key programs of foreign specialists' adoption:

- "International experts" program, where leading specialists are sent in different foreign subsidiaries for special project management;

- "Development and qualification" program: smart and talented specialists have an opportunity to work abroad for 2-3 years and to share experience after finishing the program; 
- "Influence and education" program: it is short-term internship to get successful experience and share the knowledge among colleagues.

Cross-cultural problems are prevented through holding special interviews of specialists by cross-cultural committees inside the organization. According to algorithm of attracting foreign specialists, main stages are adoption and general monitoring ones. Adoption of foreign specialists is held in the "Arkema" subsidiaries. Representatives of cross-cultural committees are responsible for general monitoring of atmosphere and satisfaction among specialists.

Russian "BIOCAD" company is much smaller than "Arkema", but it is also innovation-oriented high-technological company and it is among leaders of Russian pharmaceutical companies [3]. Level of turnover was 14 bln rubles in 2016 [3]. Subsidiaries of the company are located in Belarus, Ukraine, the USA, Brazil, India and China. Number of personnel is 1300, including 450 high-qualified specialists, many of them are members of Russian and international professional associations [3].

Great role of building effective knowledge management system in the company belongs to students and young specialists attraction, which is realized through the following directions:

- trainings in R\&D centers with appropriate externship;

- holding scientific research works on basis of R\&D centers;

- bioinformatics projects.

Key stages of the algorithm for attracting foreign specialists, mentioned above, are students attraction, preliminary long-term labor contract, adoption of new specialists (with acquaintance of cross-cultural features inside the company), and general monitoring analysis (which is held more often in American subsidiary, than in Russian one).

Summarizing, it is necessary to underline that the most important stage of foreign specialists attraction algorithm is the second stage of realizing correct adoption, because it is possible to overcome potential cross-cultural problems and conflicts in a whole organization in frames of achieving necessary aims on this stage.
Cross-cultural factors estimation is more effective to be held through special group of parameters. Periodical analysis of the meanings can help to build an effective knowledge management system of an organization.

\section{REFERENCES}

[1] Ансофф И. Новая корпоративная стратения СПб.: Питер, 1999. [Ansoff I. New corporate strategy. St Petersburg: Piter, 1999].

[2] Reference document 2017 including the Annual Financial report // Arkema.

URL: https://www.arkema.com/export/sites/global/.content/medias/downloads/ investorrelations/en/finance/arkema-2017-reference-document.pdf.

[3] BIOCAD company. https://biocad.ru/uploads/ru/files/BIOCAD 15.04.pdf.

[4] Fine L.G. The SWOT analysis: using your strength to overcome weaknesses, using opportunities to overcome threats. 2009. URL: http://lawrencefine.com/downloads/SWOT\%20-\%20PDF.pdf.

[5] Финкельштейн С. Ошибки топ-менеджеров ведущих корпораций. Анализ и практические результаты. М.: Альпина Бизнес Букс, 2006 [Finkelshtein S. Top-managers' mistakes of leading corporations. Analysis and practical results. Moscow: Alpina Business Books, 2006].

[6] Friedman T.L. The World is Flat: A Brief History of the Twenty First Century. [S.1.:] Findaway World, 2006.

[7] Гусева Н.И. Теоретические и методологические основы кросскультурных исследований // Известия Иркутской государственной экономической академии. 2003. № 3-4. С. 82-86. [Guseva N. I. Theoretical and methodological principles of cross-cultural research // Izvestiya of Irkutsk State Economic Academy. 2003. №3-4. P. 82-86].

[8] Hannan M.T., Freeman J. Organizational ecology. Cambridge: Harvard University Press, 1993.

[9] Hofer C. W., Schendel D. Strategy formulation: analytical concepts (the West series in business policy and planning). St Paul: West Publishing Company, 1978.

[10] Холден Н.Дж. Кросс-культурный менеджмент. М.: Юнити-Дана, 2005. [Holden N.J. Cross-cultural management. Concept of cognitive management. Moscow: Yuniti-Dana, 2005].

[11] Mintzberg H. The structuring of organizations. Prentice Hall, 1979.

[12] Moore F. Transnational business cultures: life and work in a multinational corporation (cross-cultural management). Hants: Ashgate Pub Ltd, 2005.

[13] Normann R., Ramirez R. Designing interactive strategy: from value chain to value constellation. Chichester: Wiley \& Sons, 1998.

[14] Porter M. E. Competitive strategy: techniques for analyzing industries and competitors. New York: Free Press, 1998.

[15] Рязанцев С.В. Глобальный рынок труда и международная миграция. M.: Экономика, 2010. [Ryazantsev S.V. The global labor market and international migration. Moscow: Economics Publishing House, 2010]. 